\title{
The Use of Teaching Aids in the Teaching and Learning of Arabic Language Vocabulary
}

\author{
Irma Martiny Md. Yasim¹, Maimun Aqsha Lubis², Zaid Arafat Mohd Noor¹, \\ Mohd Yusri Kamarudin 1 \\ ${ }^{1}$ Ministry of Education, Putrajaya, Malaysia \\ ${ }^{2}$ Faculty of Education, National University of Malaysia, Bangi, Malaysia \\ Email:irmamartiny@yahoo.com,mal@ukm.edu.my,zaid.noor@moe.gov.my,yusriqanun@yahoo.com
}

Received 2 February 2016; accepted 13 March 2016; published 16 March 2016

Copyright () 2016 by authors and Scientific Research Publishing Inc.

This work is licensed under the Creative Commons Attribution International License (CC BY).

http://creativecommons.org/licenses/by/4.0/

(c) (i) Open Access

\begin{abstract}
Vocabulary is an important component in acquisition of a language. The use of teaching aids can improve students' mastery of vocabulary learning. This study aims to identify the use of teaching aids in the teaching and learning of Arabic Language Vocabulary at National Religious Secondary Schools and Government-aided Religious Schools from the perspective of teachers and students. This study uses a survey based on a set of questionnaire as instrument of data collection method which involves 31 teachers and 324 Form Four students who are randomly selected from secondary schools in Malaysia. The results show that the usage of teaching aids in teaching and learning of Arabic vocabulary is at a moderate level. Pedagogical implications of study show that teachers need to constantly improve the use of textbooks and dictionaries as the main teaching aids and try to enhance students' mastery of vocabulary learning by diversifying the other types of teaching aids.
\end{abstract}

\section{Keywords}

Language Learning Material, Vocabulary, Foreign Language and Arabic Languages

\section{Introduction}

Vocabulary is one of the language aspects that should be emphasized in the teaching and learning of foreign languages. Vocabulary is the key component in second language teaching. The failure to master the vocabulary will lead to weaknesses in other language skills such as listening, speaking, reading and writing. Therefore, vocabulary should be pursued in language activities to improve students' language proficiency (Hamid, 2010). As 
one of the foreign languages offered at secondary schools in Malaysia, the level of Arabic Language Vocabulary mastery among the students still do not reach satisfactory level (Hussin, 2002; Yasim, 2012).

The easiest way to master new vocabulary is by using the translation method. The use of translation method is an easy, quick and effective way to introduce new vocabulary (Harmer, 2015; Hedge, 2003; Lubis, 2009). However, this method does not encourage students to interact with the words learned. Plus, the students may not be able to transfer their knowledge to real life situations very well (Lubis, 2009; Prince, 1996). Similarly, vocabulary can be taught by using a dictionary to find the meaning of new words. These new words will be recorded in a notebook and the notebook can be used as the students' personal dictionary (Schmitt, 2000). Nation (2013) also suggests a similar strategy by using "word cards" which consist of words and notes. There is no doubt that a conservative approach such as textbooks and print dictionaries is still relevant in vocabulary teaching and learning. However, the use of teaching aid depends on competence of teachers, level of student achievement and time allocate. Teachers must ensure that the use of teaching aid meets the students' individual need (Block, 1991).

The study done in vocabulary teaching and learning shows that the use of teaching aids can increase the level of students' mastery of vocabulary (Awang, 1995). Accordingly, this study aims to identify the level of use of teaching aids in the teaching and learning of Arabic Language Vocabulary (ALV) from the perspective of teachers and students.

\section{Methods}

This research is a cross-sectional survey by using a questionnaire to collect the data. The reliability of this instrument is at the highest level where the value of Alpha Cronbach is 0.90. The questionnaire is adapted from qualitative studies done by eight experienced Islamic Education Master Teachers i.e. Jasmi \& Tamuri (2011). The questionnaire consists of two parts, namely Part A and Part B. Part A is related to the student's background. Part B consists of thirteen questions related to the use of additional materials in the teaching and learning of ALV.

Descriptive data analysis methods are used to show the practice of the teaching and learning of ALV from the perspective of both teachers and students. The findings are presented in Table 1 . The data obtained are analyzed and interpreted based on mean interpretations used by Nurazan (2004).

\section{Findings}

The study involves 324 Form Four students and 31 teachers who are randomly selected as the sample of the study from eight secondary schools in Malaysia. All schools offer Arabic as a compulsory subject. The demographic of sample and the finding of study are shown in Table 2.

\subsection{What Is the Level of the Teaching Aids Usage in the Teaching and Learning of ALV from the Perspective of the Teachers?}

According to Table 3, the results show that only $21.4 \%$ of the items i.e. 3 out of 14 items are at a high level. The items are E42, E43 and E44. A total of 57.2\% of the items i.e. 8 out of 14 items are moderate. The moderate items are E40, E41, E45, E46, E47, E48, E50 and E51. The findings also show that $21.4 \%$ of the items i.e. 3 out of 14 items are at low level. The items at low level are E49, E52 and E53. The highest mean is item E42 while the lowest mean is item E52. Overall, the level of usage of the teaching aids in the teaching and learning of ALV from the perspective of the teachers are at a moderate level (mean 2.67). The teaching aids that are frequently used in teaching ALV from the perspective of the teachers are the textbook, dictionary and worksheets. The results also show that the least teaching aids used are the TV, tape recorder and overhead projector.

\subsection{What Is the Level of Teaching Aids Usage in the Teaching and Learning of ALV from the Perspective of the Students?}

Based on Table 4, the results show that $14.3 \%$ of the items i.e. 2 of 14 practices are at a high level. The items are E42 and E43. A total of 71.4\% i.e. 10 of the 14 practices are at a moderate level. The items are D40, D41, D44, D45, D46, D47, D48, D49, D50 and D51. The findings also show that 14.3\% i.e. 2 of 14 practices are at low 
Table 1. Interpretation of the mean score.

\begin{tabular}{cc}
\hline Mean Score & Interpretation \\
$1.00-1.99$ & Low \\
$2.00-2.99$ & Moderate \\
$3.00-4.00$ & High \\
\hline
\end{tabular}

Adapted from Norazan (2004).

Table 2. Samplesof study.

\begin{tabular}{|c|c|c|c|c|c|c|}
\hline \multirow{2}{*}{ Type of Schools } & \multicolumn{3}{|c|}{ Teachers } & \multicolumn{3}{|c|}{ Students } \\
\hline & Male & Female & Total & Male & Female & Total \\
\hline National Religious Secondary Schools & 7 & 8 & 15 & 63 & 96 & 159 \\
\hline Government-aided Religious Schools & 7 & 9 & 16 & 71 & 94 & 165 \\
\hline TOTAL & 14 & 17 & 31 & 159 & 165 & 324 \\
\hline
\end{tabular}

Table 3. The level of the teaching aids used in the teaching and learning of arabic language vocabulary from the perspective of the teachers.

\begin{tabular}{|c|c|c|c|c|c|c|c|}
\hline Teaching Aids & Never & $\begin{array}{l}\text { Quite } \\
\text { Often }\end{array}$ & Often & $\begin{array}{l}\text { Very } \\
\text { Often }\end{array}$ & Mean & $\mathrm{SD}$ & Interpretation \\
\hline $\begin{array}{l}\text { [E40] Teacher use multiple teaching aids to teach } \\
\text { Arabic Language Vocabulary. }\end{array}$ & - & $\begin{array}{l}(11) \\
35.5\end{array}$ & $\begin{array}{l}(16) \\
51.6\end{array}$ & $\begin{array}{l}(4) \\
12.9\end{array}$ & 2.77 & 0.669 & Moderate \\
\hline $\begin{array}{l}\text { [E41] Teacher use multiple teaching aids which } \\
\text { attracted students. }\end{array}$ & - & $\begin{array}{l}(14) \\
45.2\end{array}$ & $\begin{array}{l}(14) \\
45.2\end{array}$ & $\begin{array}{l}(3) \\
9.7\end{array}$ & 2.65 & 0.661 & Moderate \\
\hline $\begin{array}{l}\text { [E42] Teacher use textbook as teaching aid to teach } \\
\text { Arabic Language Vocabulary. }\end{array}$ & - & $\begin{array}{l}(2) \\
6.5\end{array}$ & $\begin{array}{l}(14) \\
45.2\end{array}$ & $\begin{array}{l}(15) \\
48.4\end{array}$ & 3.42 & 0.620 & High \\
\hline $\begin{array}{l}\text { [E43] Teacher use dictionaries as teaching aid to } \\
\text { teach Arabic Language Vocabulary. }\end{array}$ & - & $\begin{array}{l}(9) \\
29.0\end{array}$ & $\begin{array}{l}(9) \\
29.0\end{array}$ & $\begin{array}{l}(13) \\
41.9\end{array}$ & 3.13 & 0.846 & High \\
\hline $\begin{array}{l}\text { [E44] Teacher use work sheet as teaching aid to } \\
\text { teach Arabic Language Vocabulary. }\end{array}$ & - & $\begin{array}{l}(5) \\
16.1\end{array}$ & $\begin{array}{l}(17) \\
54.8\end{array}$ & $\begin{array}{l}(9) \\
29.0\end{array}$ & 3.13 & 0.670 & High \\
\hline $\begin{array}{l}\text { [E45] Teacher use "Mahjong" Paper sheet as } \\
\text { teaching aid to teach Arabic Language Vocabulary. }\end{array}$ & - & $\begin{array}{l}(6) \\
19.4\end{array}$ & $\begin{array}{l}(13) \\
41.9\end{array}$ & $\begin{array}{l}(11) \\
35.5\end{array}$ & 2.23 & 0.805 & Moderate \\
\hline $\begin{array}{l}\text { [E46] Teacher use charts as teaching aid to teach } \\
\text { Arabic Language Vocabulary. }\end{array}$ & $\begin{array}{l}(4) \\
12.9\end{array}$ & $\begin{array}{l}(13) \\
41.9\end{array}$ & $\begin{array}{l}(12) \\
38.7\end{array}$ & $\begin{array}{l}(2) \\
6.5\end{array}$ & 2.39 & 0.803 & Moderate \\
\hline $\begin{array}{l}\text { [E47] Teacher use software and LCD as teaching } \\
\text { aid to teach Arabic Language Vocabulary. }\end{array}$ & $\begin{array}{l}(9) \\
29.0\end{array}$ & $\begin{array}{l}(11) \\
35.5\end{array}$ & $\begin{array}{l}(11) \\
35.5\end{array}$ & - & 2.06 & 0.814 & Moderate \\
\hline $\begin{array}{l}\text { [E48] Teacher use software and LCD as teaching } \\
\text { aid to teach Arabic Language Vocabulary. }\end{array}$ & $\begin{array}{l}(10) \\
32.3\end{array}$ & $\begin{array}{l}(13) \\
41.9\end{array}$ & $\begin{array}{l}(6) \\
19.4\end{array}$ & $\begin{array}{l}(2) \\
6.5\end{array}$ & 2.00 & 0.894 & Moderate \\
\hline $\begin{array}{l}\text { [E49] Teacher use OHP or Visualizer as teaching } \\
\text { aid to teach Arabic Language Vocabulary. }\end{array}$ & $\begin{array}{l}(17) \\
54.8\end{array}$ & $\begin{array}{l}(10) \\
32.3\end{array}$ & $\begin{array}{l}(3) \\
9.7\end{array}$ & $\begin{array}{l}(1) \\
3.2\end{array}$ & 1.61 & 0.803 & Low \\
\hline $\begin{array}{l}\text { [E50] Teacher use pictures as teaching aid to teach } \\
\text { Arabic Language Vocabulary. }\end{array}$ & $\begin{array}{l}(6) \\
19.4\end{array}$ & $\begin{array}{l}(11) \\
35.5\end{array}$ & $\begin{array}{l}(12) \\
38.7\end{array}$ & $\begin{array}{l}(2) \\
6.5\end{array}$ & 2.32 & 0.871 & Moderate \\
\hline $\begin{array}{l}\text { [E51] Teacher use real object as teaching aid to } \\
\text { teach Arabic Language Vocabulary. }\end{array}$ & $\begin{array}{l}(5) \\
16.1\end{array}$ & $\begin{array}{l}(10) \\
32.3\end{array}$ & $\begin{array}{l}(15) \\
48.4\end{array}$ & $\begin{array}{l}(1) \\
3.2\end{array}$ & 2.39 & 0.803 & Moderate \\
\hline $\begin{array}{l}\text { [E52] Teacher use TV as teaching aid to teach } \\
\text { Arabic Language Vocabulary. }\end{array}$ & $\begin{array}{l}(23) \\
74.2\end{array}$ & $\begin{array}{l}(6) \\
19.4\end{array}$ & $\begin{array}{l}(2) \\
6.5\end{array}$ & - & 1.32 & 0.599 & Low \\
\hline $\begin{array}{l}\text { [E53] Teacher use recorder as teaching aid to teach } \\
\text { Arabic Language Vocabulary. }\end{array}$ & $\begin{array}{l}(16) \\
51.6\end{array}$ & $\begin{array}{l}(12) \\
38.7\end{array}$ & $\begin{array}{l}(3) \\
9.7\end{array}$ & - & 1.58 & 0.672 & Low \\
\hline
\end{tabular}


Table 4. The level of teaching aids used in the teaching and learning of arabic language vocabulary from the perspective of the students.

\begin{tabular}{|c|c|c|c|c|c|c|c|}
\hline Teaching Aids & Never & $\begin{array}{l}\text { Quite } \\
\text { Often }\end{array}$ & Often & $\begin{array}{l}\text { Very } \\
\text { Often }\end{array}$ & Mean & SD & Interpretation \\
\hline $\begin{array}{l}\text { [E40] Teacher use multiple teaching aids to teach } \\
\text { Arabic Language Vocabulary. }\end{array}$ & $\begin{array}{l}(26) \\
8.0\end{array}$ & $\begin{array}{l}(108) \\
33.3\end{array}$ & $\begin{array}{l}(124) \\
38.3\end{array}$ & $\begin{array}{l}(66) \\
20.4\end{array}$ & 2.71 & 0.881 & Moderate \\
\hline $\begin{array}{l}\text { [E41] Teacher use multiple teaching aids which } \\
\text { attracted students. }\end{array}$ & $\begin{array}{l}(34) \\
10.5\end{array}$ & $\begin{array}{l}(123) \\
38.0\end{array}$ & $\begin{array}{l}(101) \\
31.2\end{array}$ & $\begin{array}{l}(66) \\
20.4\end{array}$ & 2.61 & 0.926 & Moderate \\
\hline $\begin{array}{l}\text { [E42] Teacher use textbook as teaching aid to teach } \\
\text { Arabic Language Vocabulary. }\end{array}$ & $\begin{array}{l}(2) \\
0.6\end{array}$ & $\begin{array}{l}(55) \\
17.0\end{array}$ & $\begin{array}{l}(125) \\
38.6\end{array}$ & $\begin{array}{l}(142) \\
43.8\end{array}$ & 3.26 & 0.754 & High \\
\hline $\begin{array}{l}\text { [E43] Teacher use dictionaries as teaching aid to teach } \\
\text { Arabic Language Vocabulary. }\end{array}$ & $\begin{array}{l}(22) \\
6.8\end{array}$ & $\begin{array}{l}(58) \\
17.9\end{array}$ & $\begin{array}{l}(133) \\
41.0\end{array}$ & $\begin{array}{l}(111) \\
34.3\end{array}$ & 3.03 & 0.892 & High \\
\hline $\begin{array}{l}\text { [E44] Teacher use work sheet as teaching aid to teach } \\
\text { Arabic Language Vocabulary. }\end{array}$ & $\begin{array}{l}(28) \\
8.6\end{array}$ & $\begin{array}{l}(82) \\
25.3\end{array}$ & $\begin{array}{l}(143) \\
44.1\end{array}$ & $\begin{array}{l}(71) \\
21.9\end{array}$ & 2.79 & 0.882 & Moderate \\
\hline $\begin{array}{l}\text { [E45] Teacher use "Mahjong" Paper sheet as teaching } \\
\text { aid to teach Arabic Language Vocabulary. }\end{array}$ & $\begin{array}{l}(71) \\
21.9\end{array}$ & $\begin{array}{l}(89) \\
27.5\end{array}$ & $\begin{array}{l}(107) \\
33.0\end{array}$ & $\begin{array}{l}(57) \\
17.6\end{array}$ & 2.46 & 1.021 & Moderate \\
\hline $\begin{array}{l}\text { [E46] Teacher use charts as teaching aid to teach } \\
\text { Arabic Language Vocabulary. }\end{array}$ & $\begin{array}{l}(68) \\
21.0\end{array}$ & $\begin{array}{l}(132) \\
40.7\end{array}$ & $\begin{array}{l}(91) \\
28.1\end{array}$ & $\begin{array}{l}(33) \\
10.2\end{array}$ & 2.27 & 0.908 & Moderate \\
\hline $\begin{array}{l}\text { [E47] Teacher use software and LCD as teaching aid } \\
\text { to teach Arabic Language Vocabulary. }\end{array}$ & $\begin{array}{l}(96) \\
29.6\end{array}$ & $\begin{array}{l}(102) \\
31.5\end{array}$ & $\begin{array}{l}(75) \\
23.1\end{array}$ & $\begin{array}{l}(51) \\
15.7\end{array}$ & 2.25 & 1.048 & Moderate \\
\hline $\begin{array}{l}\text { [E48] Teacher use software and LCD as teaching aid } \\
\text { to teach Arabic Language Vocabulary. }\end{array}$ & $\begin{array}{l}(110) \\
34.0\end{array}$ & $\begin{array}{l}(115) \\
35.5\end{array}$ & $\begin{array}{l}(65) \\
20.1\end{array}$ & $\begin{array}{l}(34) \\
10.5\end{array}$ & 2.07 & 0.979 & Moderate \\
\hline $\begin{array}{l}\text { [E49] Teacher use OHP or Visualizer as teaching aid } \\
\text { to teach Arabic Language Vocabulary. }\end{array}$ & $\begin{array}{l}(109) \\
33.6\end{array}$ & $\begin{array}{l}(113) \\
34.9\end{array}$ & $\begin{array}{l}(74) \\
22.8\end{array}$ & $\begin{array}{l}(28) \\
8.6\end{array}$ & 2.06 & 0.953 & Moderate \\
\hline $\begin{array}{l}\text { [E50] Teacher use pictures as teaching aid to teach } \\
\text { Arabic Language Vocabulary. }\end{array}$ & $\begin{array}{l}(78) \\
24.1\end{array}$ & $\begin{array}{l}(107) \\
33.0\end{array}$ & $\begin{array}{l}(86) \\
26.5\end{array}$ & $\begin{array}{l}(53) \\
16.4\end{array}$ & 2.35 & 1.020 & Moderate \\
\hline $\begin{array}{l}\text { [E51] Teacher use real object as teaching aid to teach } \\
\text { Arabic Language Vocabulary. }\end{array}$ & $\begin{array}{l}(85) \\
26.2\end{array}$ & $\begin{array}{l}(99) \\
30.6\end{array}$ & $\begin{array}{l}(84) \\
25.9\end{array}$ & $\begin{array}{l}(56) \\
17.3\end{array}$ & 2.34 & 1.048 & Moderate \\
\hline $\begin{array}{l}\text { [E52] Teacher use TV as teaching aid to teach Arabic } \\
\text { Language Vocabulary. }\end{array}$ & $\begin{array}{l}(129) \\
39.8\end{array}$ & $\begin{array}{l}(112) \\
34.6\end{array}$ & $\begin{array}{l}(50) \\
15.4\end{array}$ & $\begin{array}{l}(33) \\
10.2\end{array}$ & 1.96 & 0.980 & Low \\
\hline $\begin{array}{l}\text { [E53] Teacher use recorder as teaching aid to teach } \\
\text { Arabic Language Vocabulary. }\end{array}$ & $\begin{array}{l}(132) \\
40.7\end{array}$ & $\begin{array}{l}(109) \\
33.6\end{array}$ & $\begin{array}{l}(60) \\
18.5\end{array}$ & $\begin{array}{l}(23) \\
7.1\end{array}$ & 1.92 & 0.934 & Low \\
\hline
\end{tabular}

levels. The items are E52 and E53. The highest mean is item E42 while the lowest mean is item E53. Overall, the level of teaching aids usage in the teaching and learning of vocabulary in Arabic from the perspective of the students are at a moderate level (mean 2.62). The textbooks and dictionaries are the teaching aids that are used frequently in teaching vocabulary in Arabic and the least used teaching aids are the TV and the tape recorder.

\section{Discussion and Conclusion}

The level of teaching aids usage in the teaching and learning of ALV from the perspective of the students and teachers is at a moderate level. This finding is consistent with the other studies in the field of Arabic and Islamic education. In their studies, Yusoff \& Ghani (2008) and Jasmi \& Tamuri (2011) show that the teaching aids are not being fully utilized in the classroom.

The level of teaching aids usage in the form of non-electronic for teaching and learning ALV is high. The high dependency on the use of textbook shows that it is widely used in Arabic teaching and learning in Malaysia. This situation is in line with the instructions stated in the Ministry of Education's Circular 12/1999, which requires the use of textbooks and exercise books as recommended by the ministry. The textbook used is considered to meet the characteristics of teaching aids that should explain vague and difficult ideas, contain beautiful colours, have appropriate size and should be durable, cost effective and can give a big impact in teaching and learning (Jasmi \& Tamuri, 2007).

The high use of dictionary in this study contradicts Mohamad (2003) study that finds the use of dictionaries among the students and teachers are at an unsatisfactory level. However, her research shows that the use of a 
dictionary helps the students to answer the questions in their tests and examinations. The use of a dictionary can also encourage the students to learn the language and increase the size of their vocabulary (Aminah \& Hasnah, 2015). In terms of the types of dictionary to be used, Ahmad Riza et al. (2005) find that more students prefer to use Arab-Malay dictionary than Arabic-Arabic dictionary. The use of electronic teaching aids is at a moderate level. The level may be caused by the following factors: the lack of availability of the teaching aids, they are not user-friendly, the lack of knowledge concerning the handling of such teaching aids or they are not being provided by the school (Harun, Ruskam, Baharuddin, Othman, \& Sarip, 2015).

In conclusion, the use of teaching aids, both electronic and non-electronic forms need to be enhanced in ALV teaching and learning process. This is because the use of teaching aids can improve the effectiveness of teaching and learning, improve the knowledge and skills and should complement the teaching methods that are constantly changing over time (Harun et al., 2015).

\section{Implications of Study}

The findings of the study have direct implications for teaching and learning ALV, especially in Malaysia. Curriculum Development Division of the Ministry of Education should provide ALV word lists that meet the needs of the students. The word list could be formed from the combination of thematic and frequent word list. Ministry of Education's Textbook Division should also pay special attention to the aspects of vocabulary that should be mastered by the students during the preparation of textbooks. For example, the high frequency vocabulary ought to be printed in coloured fonts. The instructions on how to use the dictionary should be explained in details in the textbooks. As such, it would help the teachers and students in teaching and learning this foreign language. Students can get information such as spelling, pronunciation, etymology and the usage of the word by using dictionaries because entries in any dictionary usually contains words that are common, widespread and high frequency of use (Nasuka \& Saidin, 2014). Teachers also need to diversify the use of teaching aids so that the Arabic vocabulary stated in the Arabic Language Syllabus can be mastered by the students. Teachers also have to teach the students about how to use the dictionary to get the exact meaning of a new word learned. Teachers also need to expose the students to various vocabulary learning strategies to be used in the classroom, outside the classroom or during an exam. Vocabulary learning strategies such as memorizing strategies can help the students to master the vocabulary in Arabic.

\section{References}

Aminah, N., \& Hasnah (2015). Dictionary and Its Role to Enhance the Interest in Children Learning Language. International Journal of Malay World and Civilization, 3, 79-89.

Awang, A. (1995). The Effect of Teaching Aids to Mastery Vocabulary in Arabic Form One at a Secondary School. Kuala Lumpur: Universiti Malaya.

Block, D. (1991). Some Thoughts on DIY Materials Design. ELT Journal, 45, 211-217. http://doi.org/10.1093/elt/45.3.211

Hamid, H. A. (2010). Teaching Vocabulary in Lower Secondary stage. Kuala Lumpur: Universiti Malaya.

Harmer, J. (2015). The Practice of English Language Teaching. United Kingdom: Pearson Education ESL.

Harun, M. A. W., Ruskam, A., Baharuddin, A. S., Othman, R., \& Sarip, M. A. A. (2015). Epistemology of Practice Teaching Aids "Nabawi" in Teaching and Learning. International Journal of Islamic and Civilization Studies, 2, 45-55.

Hedge, T. (2003). The Practice of English Language Teaching. ELT Journal, 57, 401-405. http://doi.org/10.1093/elt/57.4.401

Hussin, S. (2002). Achievement of ARABIC Vocabulary among Students in Form Three: A Case Study in SMKA in Melaka. Kuala Lumpur: Universiti Malaya.

Jasmi, K. A., \& Tamuri, A. H. (2007). Islamic Education: Teaching and Learning Methods. Skudai: Penerbit Universiti Teknologi Malaysia.

Jasmi, K. A., \& Tamuri, A. H. (2011). The Practice in the of Usage of Teaching Aids in Circles Outstanding Teacher of Islamic Education Schools in Malaysia. Journal of Islamic and Arabic Education, 3, 59-74.

Lubis, M. A. (2009). Teaching and Learning Arabic Language through Multicultural Approach and Applying ICT in Pesantren Institution. International Journal of Education and Information Technologies, 3, 171-178.

Mohamad, N. (2003). The Use of Arab-Malay Dictionary among Secondary School Students. Kuala Lumpur: Universiti Malaya.

Nasuka, A. binti, \& Saidin, S. N. R. binti. (2014). Strengths and Weaknesses in Bilingual Dictionaries To Help a Translator. 
Procedia-Social and Behavioral Sciences, 134, 364-372. http://doi.org/10.1016/j.sbspro.2014.04.258

Nation, I. S. P. (2013). Learning Vocabulary in Another Language. Cambridge: Cambridge University Press.

Nurazan, M. R. (2004). The Learning Strategies in the Teaching of Arabic in Kusza. Bangi: Universiti Kebangsaan Malaysia.

Prince, P. (1996). Second Language Vocabulary Learning: The Role of Context versus Translations as a Function of Proficiency. The Modern Language Journal, 80, 478-493. http://doi.org/doi:10.1111/j.1540-4781.1996.tb05468.x

Schmitt, N. (2000). Vocabulary in Language Teaching. TESOL Quarterly, 36, 235. http://doi.org/10.2307/3588334

Yasim, I. M. M. (2012). The Relationship between Vocabulary Learning Strategy and Vocabulary Mastery Level Students. Bangi: Universiti Kebangsaan Malaysia.

Yusoff, N. M. R. N., \& Ghani, K. A. (2008). The Use of Teaching Aids and Its Relationship with the Arabic Language Listening Skills. Jurnal Teknologi, 49, 141-154. 